\title{
Effects of gonadotropin-releasing hormone agonist on human chorionic gonadotropin activity in granulosa cells of immature female rats
}

\author{
Doungrut TUNGMAHASUK ${ }^{1)}$, Numfa FUNGBUN ${ }^{1}$, , Titaree LAOHARATCHATATHANIN ${ }^{2)}$, \\ Ryota TERASHIMA ${ }^{1)}$, Shiro KURUSU ${ }^{1)}$ and Mitsumori KAWAMINAMI ${ }^{1)}$ \\ 1) Laboratory of Veterinary Physiology, School of Veterinary Medicine, Kitasato University, Aomori 034-8628, Japan \\ ${ }^{2}$ Clinic for Small Domestic Animals and Radiology, Faculty of Veterinary Medicine, Mahanakorn University of Technology, \\ Bangkok 10530, Thailand
}

\begin{abstract}
Although the expression of gonadotropin-releasing hormone $(\mathrm{GnRH})$ in the ovaries is well established, its physiological role remains unknown. The aim of this study was to determine whether ovarian GnRH mediates the actions of human chorionic gonadotropin (hCG) in the granulosa cells of immature female rats. Follicular growth was induced by administration of pregnant mare serum gonadotropin (PMSG, $15 \mathrm{IU} / 0.15 \mathrm{ml}$ ) on day 25 after birth, and hCG (20 IU/0.2 ml) was administered on day 27 revealing the increase of plasma progesterone level. Primary cultures of granulosa cells were established from large follicles 2 days after PMSG treatment. Progesterone synthesis was augmented by hCG in a dosedependent manner. Annexin A5 (ANXA5), a biomarker of GnRH, was expressed in the granulosa-luteal cells after hCG treatment, as shown by immunohistochemistry, suggesting that hCG treatment induced GnRH action. The GnRH mRNA level was increased by hCG, and treatment with GnRH agonist (GnRHa) increased ANXA5 mRNA levels in the primary cultures of granulosa cells. Concomitant incubation of $\mathrm{GnRH}\left(10^{-7} \mathrm{M}\right)$ or $\mathrm{GnRHa}$ (fertirelin acetate, $\left.10^{-8} \mathrm{M}\right)$ with hCG suppressed progesterone synthesis during a $3 \mathrm{~h}$ incubation period. The mRNA expression of luteinizing hormone receptor (LHR) and follicle-stimulating hormone receptor (FSHR) was synergistically stimulated and suppressed by hCG and GnRHa, respectively. GnRHa stimulated p21 expression, and GnRHa and hCG synergistically reduced the mRNA expression levels of p27 and FOXO1. These data suggest that GnRH induced by LH may have a role for the LH-mediated luteinization of granulosa cells. In addition, ANXA5 may be involved in GnRH action. GnRH-ANXA5 would be an important mechanism in cell differentiation.
\end{abstract}

Key words: Gonadotropin-releasing hormone (GnRH), Granulosa cell, Luteinization

(J. Reprod. Dev. 64: 129-134, 2018)

G onadotropin-releasing hormone $(\mathrm{GnRH})$ is a hypothalamic neuropeptide that regulates gonadotropin secretion from pituitary gonadotropes [1]. GnRH and its receptor are also expressed in various peripheral tissues, including the ovaries [2-4]. GnRH has been related to follicular atresia and luteolysis in the ovary [5-7]. Furthermore, GnRH agonist (GnRHa) has been shown to inhibit ovarian cancer cell proliferation [8]. Although GnRH has been postulated to play important roles in tissues other than the pituitary gland, these roles have not been well defined.

During the estrous cycle, the luteinizing hormone (LH) surge causes granulosa cells of mature follicles to develop into the corpus luteum cells through a process called luteinization in which granulosa cells synthesizing estrogen differentiate into progesterone-producing luteal cells. Luteinization is characterized by abundant cell proliferation, exiting from the cell cycle, and angiogenesis [9]. During this process, the mRNA of follicle-stimulating hormone receptor (FSHR) decreases,

Received: October 27, 2017

Accepted: December 7, 2017

Published online in J-STAGE: December 15, 2017

(C)2018 by the Society for Reproduction and Development

Correspondence: M Kawaminami (e-mail: mitsumor@vmas.kitasato-u.ac.jp)

This is an open-access article distributed under the terms of the Creative Commons Attribution Non-Commercial No Derivatives (by-nc-nd) License. (CC-BY-NC-ND 4.0: https://creativecommons.org/licenses/by-nc-nd/4.0/) whereas that of LH receptor ( $L H R)$ increases in luteal cells [10].

Annexin A5 (ANXA5) is a member of the annexin family of calcium-dependent phospholipid-binding proteins, with 12 members in mammals $[11,12]$. Studies from our group and others have demonstrated that ANXA5 is expressed in a cell type-specific manner in the pituitary gland, ovary, testis, mammary gland, adrenal gland, thyroid gland, placenta, heart, and muscle [13-19]. Because ANXA5 expression is stimulated by GnRH not only in pituitary gonadotropes but also in peripheral tissues, it has been used as a biomarker of GnRH activity in various tissues $[7,16,17]$. We previously reported that GnRH stimulates ANXA5 expression and apoptosis in the corpus luteum of pseudopregnant rats [7]. Because ANXA5 is only expressed in the corpus luteum and not in granulosa cells, its synthesis is hypothesized to begin during luteinization [14].

In this study, we aimed to determine whether GnRH is involved in the process of luteinization after human chorionic gonadotropin (hCG) stimulation in the granulosa cells of immature female rats.

\section{Materials and Methods}

\section{Animals}

Female Wistar-Imamichi rats bred in our laboratory were used for all the experiments. The rats were maintained at $23 \pm 3^{\circ} \mathrm{C}$ with a light (L)-dark (D) cycle of 14L:10D (light on at 0500-1900 h). 
Food and tap water were provided ad libitum. All animal experiments were approved by the Institutional Animal Care and Use Committee of Kitasato University (Approval No. 16-028). To examine changes in plasma progesterone concentration after gonadotropin treatment of immature female rats, pregnant mare serum gonadotropin (PMSG; $15 \mathrm{IU} / 0.15 \mathrm{ml}$ ) was administered to the rats (25 days old) by intraperitoneal injection to induce follicular growth. Blood samples were collected from the abdominal aorta at 1,3,6, 12, and $24 \mathrm{~h}$ after the administration of hCG $(20 \mathrm{IU} / 0.2 \mathrm{ml})$ or saline $(0.2 \mathrm{ml})$ on day 27 under deep anesthesia with diethyl ether $(n=5)$. Heparinized blood was centrifuged and plasma was stored at $-30^{\circ} \mathrm{C}$ until the time-resolved immunofluorometric assay (TR-IFMA) for progesterone.

\section{Immunohistochemistry}

PMSG (15 IU/0.15 ml) was administered to rats on day 25 after birth, and hCG was additionally administered on day 27 . The ovaries were collected $48 \mathrm{~h}$ after PMSG and $24 \mathrm{~h}$ after hCG administration. The ovaries were fixed in $4 \%$ paraformaldehyde in $0.1 \mathrm{M}$ phosphate-buffered saline (PBS, $\mathrm{pH} 7.4$ ) at $4^{\circ} \mathrm{C}$ overnight, and then further incubated with $0.1 \mathrm{M}$ PBS at $4{ }^{\circ} \mathrm{C}$ overnight. Dehydration and paraffin embedding were performed per standard procedures. Sections of 3- $\mu \mathrm{m}$ thickness were obtained and dried overnight in an incubator at $37^{\circ} \mathrm{C}$. After dewaxing, sections were soaked in $1 \%$ hydrogen peroxide in methanol for $20 \mathrm{~min}$ to suppress internal peroxidase, and were washed with $\mathrm{ABB}(150 \mathrm{mM} \mathrm{NaCl}, 5 \mathrm{mM}$ ethylenediaminetetraacetic acid, $0.25 \%$ gelatin, $0.05 \%$ Nonidet $\mathrm{P}-40$, $50 \mathrm{mM}$ Tris, $\mathrm{pH}$ 7.4). The sections were then incubated in $2.5 \%$ normal horse serum for $1 \mathrm{~h}$ at room temperature $\left(25^{\circ} \mathrm{C}\right)$. Sections were incubated overnight at $4^{\circ} \mathrm{C}$ with a $1: 10,000$ dilution of rabbit polyclonal antiserum against ANXA5 (previously developed in our laboratory [14]), and then washed with ABB followed by incubation with the secondary antibody (ImmPRESS anti-rabbit IgG, Vector Laboratories, Burlingame, CA, USA) for $2 \mathrm{~h}$. The specimens were washed again with $A B B$, visualized with diaminobenzidine (Roche, Mannheim, Germany), and counter-stained with hematoxylin. Finally, the samples were dehydrated and mounted on coverslips.

\section{Primary culture of granulosa cells}

PMSG (15 IU/0.15 ml) was administered to the immature female rats on day 25 to induce follicular growth. Ovaries were collected $48 \mathrm{~h}$ after PMSG administration and were placed in growth medium consisting of Dulbecco's modified Eagle medium F-12 (Gibco ${ }^{\circledR}$ Life Technologies, Grand Island, NY, USA), 10 mM HEPES, 1\% antibiotic-antimycotic, and $10 \%$ fetal bovine serum ( $\mathrm{pH} 7.4$, Gibco $\left.{ }^{\circledR}\right)$. Ovaries were excised under a microscope. Granulosa cells were liberated from large follicles to the medium by puncturing the antral follicle with a 26-gauge needle; cell dissociation was facilitated by efflux and influx of the cell suspension through a glass pipet. The cells were then filtered through a cell strainer with a $70-\mu \mathrm{m}$ pore size (Becton Dickinson Biosciences, Billerica, MA, USA) and centrifuged at $133 \times g$ for $10 \mathrm{~min}$, after which the supernatant was discarded. Cells were re-suspended with growth medium and counted, and then seeded onto a 24-well culture plate at a density of 500,000 cells/ $\mathrm{ml}$ in a volume of $1 \mathrm{ml} /$ well. The cells were pre-incubated for $24 \mathrm{~h}$ before the experiment. The medium was then replaced with fresh growth medium containing the appropriate reagents according to each experimental design. To examine the effects of hCG on the progesterone production of granulosa cells, the cells were treated with different concentrations of hCG $(0.001,0.01,0.1 \mathrm{IU} / \mathrm{ml})$ for $3 \mathrm{~h}$. To examine the effects of GnRH and GnRHa (Des-Gly10 [Pro9]-GnRH ethylamide) on progesterone production stimulated by hCG as well as the effects of GnRHa on the mRNA expression of various genes, the cells were treated with $0.01 \mathrm{IU} / \mathrm{ml} \mathrm{hCG}$ and $10^{-7} \mathrm{M}$ GnRH (Sigma) or $10^{-8} \mathrm{M}$ GnRHa (Intervet, Tokyo, Japan) for $3 \mathrm{~h}$. We chose these concentrations given that GnRHa is usually more potent than the intact peptide. The growth media were collected and stored at $-30^{\circ} \mathrm{C}$ until the subsequent TR-IFMA assay. Granulosa cells were frozen in $0.5 \mathrm{ml}$ TRIzol ${ }^{\circledR}$ Reagent (Thermo Fisher Scientific, Tokyo, Japan) and stored at $-80^{\circ} \mathrm{C}$ until RNA extraction and quantitative reverse transcription-polymerase chain reaction (RT-qPCR).

\section{TR-IFMA for progesterone}

Progesterone was extracted from the plasma or medium with hexane (Kanto Chemical, Tokyo, Japan). The hexane phase was decanted into a new glass tube and evaporated with nitrogen gas. The dried samples were dissolved in $2 \mathrm{ml}$ assay buffer [ $50 \mathrm{mM}$ Tris- $\mathrm{HCl}$ buffered saline, $0.5 \%$ bovine serum albumin (BSA), $0.05 \%$ bovine gamma globulin, $0.01 \%$ Tween 20, $20 \mu \mathrm{M}$ Diethylenetriamine$N, N, N^{\prime}, N^{\prime \prime}, N^{\prime \prime}$-pentaacetic acid, $15 \mathrm{mg} / 1$ phenol red, $0.05 \% \mathrm{NaN}_{3}$, pH 7.8]. BSA-conjugated progesterone (4-PREGNEN-3, 20-DIONE 3-O-CARBOXYMETHYLOXIME: BSA, Steraloids, Newport, RI, USA) was diluted in coating buffer $\left(50 \mathrm{mM} \mathrm{K}_{2} \mathrm{HPO}_{4}, 0.05 \% \mathrm{NaN}_{3}\right.$, $0.9 \% \mathrm{NaCl}$ ) to $3 \mu \mathrm{g} / \mathrm{ml}$ and added to each well of a 96 -well assay plate (Thermo Scientific, Roskilde, Denmark) at a volume of $100 \mu 1 /$ well, after which the plate was shaken at room temperature overnight. The wells were washed three times with wash buffer $(0.9 \% \mathrm{NaCl}$, $0.05 \%$ Tween 20 ), $200 \mu \mathrm{l} /$ well blocking solution ( $50 \mathrm{mM} \mathrm{Na}_{2} \mathrm{HPO}_{4}$, $0.1 \%$ BSA) was added to the wells, and the plate was shaken at $4{ }^{\circ} \mathrm{C}$ overnight. After the plate was washed three times, anti-progesterone $\mathrm{IgG}$ was prepared from homemade anti-progesterone rabbit serum using the Protein G HP Spin Trap kit (GE Healthcare Life Sciences, Uppsala, Sweden), and the IgG was labeled with europium (Eu) using DELFIA ${ }^{\circledR}$ Eu-Labelling Kit (PerkinElmer, Turku, Finland). Eu-labeled IgG was diluted with assay buffer and added to the plate at a volume of $100 \mu \mathrm{l} /$ well. Progesterone standards and samples (100 $\mu 1 /$ well) were added to the plate. Fluorescence was measured by PerkinElmer's 2030 multi label reader after the addition of 100 $\mu 1$ enhancement solution (PerkinElmer) and then shaken for $5 \mathrm{~min}$.

\section{RNA extraction and RT- $q P C R$}

RNA was extracted from granulosa cells with Trizol Reagent, and total RNA was measured with the NanoDrop 2000 spectrophotometer (Thermo Scientific, Wilmington, DE, USA). RNA was reverse-transcribed to cDNA with the High Capacity cDNA Reverse Transcription Kit (Applied Biosystems, Carlsbad, CA, USA). The cDNA samples were subjected to qPCR to examine the mRNA expression levels of GnRH, ANXA5, LHR, FSHR, p21, p27, and FOXO1. Primer sequences for each gene and ribosomal protein L19 (RPL19) are shown in Table 1. The PCR mixture consisted of Power SYBR ${ }^{\circ}$ Green PCR Master Mix (Applied Biosystems, UK), $300 \mathrm{nM}$ forward and reverse primers, UltraPure ${ }^{\mathrm{TM}}$ Distilled Water (Life Technologies), and $1 \mu \mathrm{l}$ cDNA in a total volume of $10 \mu 1$. The 
Table 1. Primer sequences for RT-qPCR

\begin{tabular}{lll}
\hline \multicolumn{1}{c}{ Target } & \multicolumn{1}{c}{ Forward primer } & \multicolumn{1}{c}{ Reverse primer } \\
\hline GnRH & GGCAAGGAGGAGGATCAAA & CCAGTGCATTACATCTTCTTCTG \\
ANXA5 & GGAAACCATTGACCGAGAGA & TCTCTGCAAGGTAGGCAGGT \\
$p 21$ & CACGAAACAGGCTCAGGAGT & GCATCGTCAACACCCTGTCT \\
$p 27$ & CCAGACGTAAACAGCTCCGAA & CTCAGTGCTTATACAGGATGTCC \\
LHR & GGCACACCATCACCTATGCT & AAAAGAGCCATCCTCCGAGC \\
$F S H R$ & TCTCTGCATGGCCCCAATT & GGCCTTGGACACAGTGATGA \\
$F O X O 1$ & AGGAGTTAGTGAGCAGGCAAC & GGGTGAAGGGCATCTTTGGA \\
RPL19 & CAGGAGATACCGGGAATCTAAG & TGCCTTCAGTTTGTGGTGTG \\
\hline
\end{tabular}

delta-delta $\mathrm{Ct}$ method was used for normalization of gene expression levels using RPL19 as the reference gene.

\section{Statistical analysis}

Statistical significance was assessed by analysis of variance followed by Tukey's test, with P values less than 0.05 indicating statistical significance. Paired comparisons were analyzed by Student's $t$-test with $\mathrm{p}$ values less than 0.01 indicating significance.

\section{Results}

Changes in progesterone levels in response to hCG

PMSG was administered to immature rats on day 25 , and plasma progesterone levels were examined after hCG treatment on day 27 after birth. The progesterone level significantly increased after hCG treatment until $6 \mathrm{~h}(\mathrm{P}<0.05)$, after which the levels gradually decreased during the $24 \mathrm{~h}$ experimental period (Fig. 1A). Primary cultures of granulosa cells were prepared $48 \mathrm{~h}$ after PMSG administration. After 1 day of pre-incubation, the cells were challenged with hCG, and the resultant dose-dependent response in progesterone production was confirmed after a $3 \mathrm{~h}$ incubation (Fig. 1B). Granulosa cells responded to $0.001 \mathrm{IU} / \mathrm{ml} \mathrm{hCG}$ to produce a significant amount of progesterone. Based on these results, a concentration of $0.01 \mathrm{IU} / \mathrm{ml}$ hCG was used for subsequent experiments.

\section{ANXA5 and GnRH expression in granulosa cells}

ANXA5 expression was examined by immunohistochemistry. ANXA5 was not detected in granulosa cells before hCG treatment (Fig. 2A). ANXA5 was only observed in interstitial tissues $48 \mathrm{~h}$ after PMSG administration but was observed in granulosa-luteal cells 24 $\mathrm{h}$ after hCG administration. In primary cultures of granulosa cells, the GnRH mRNA expression level was significantly increased by $\mathrm{hCG}$ during the $3 \mathrm{~h}$ incubation (Fig. 2B). In turn, GnRHa treatment increased the ANXA5 mRNA expression level (Fig. 2B). Granulosa cells were then treated with a combination of GnRH and GnRHa to determine their combined effects on the hCG-mediated increase of progesterone production in the primary cultures of granulosa cells. The results showed that GnRH and GnRHa did not significantly affect basal progesterone production but significantly suppressed hCG-stimulated progesterone production during the $3 \mathrm{~h}$ incubation period (Fig. 3A, B).

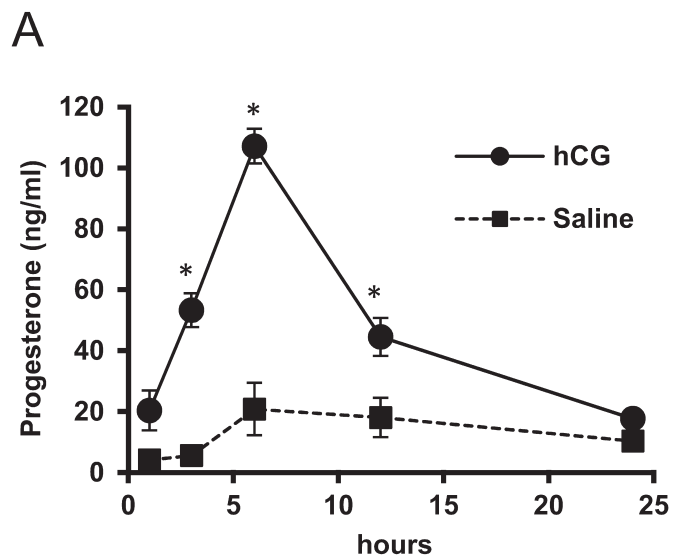

B

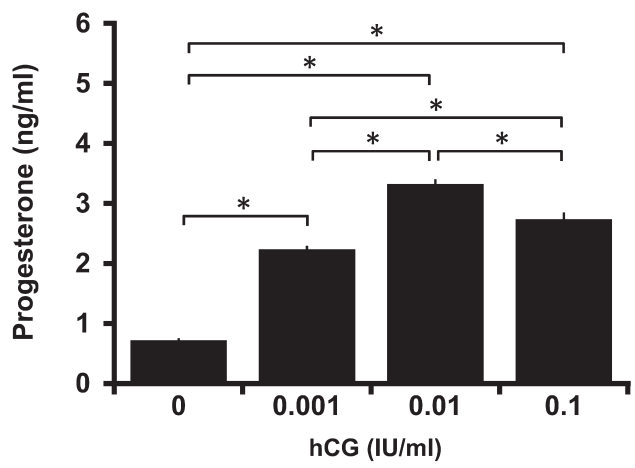

Fig. 1. Changes in progesterone levels in response to hCG. (A) PMSGtreated rats were administered $\mathrm{hCG}$ at $48 \mathrm{~h}$ after PMSG treatment, and plasma samples were collected after hCG administration for $24 \mathrm{~h}$. Values are mean \pm SEM of five rats. Asterisks indicate a significant difference from the saline-treated control at the same sampling point $(\mathrm{P}<0.05)$. (B) Granulosa cells were treated with various concentrations of hCG $(0.001,0.01,0.1 \mathrm{IU} / \mathrm{ml})$ for 3 h. Values are mean \pm SEM. Asterisks indicate values that are significantly different between groups $(\mathrm{P}<0.05)$.

Effects of GnRHa on gene expression in granulosa cells upon hCG treatment

The effects of GnRHa on the expression of genes related to luteinization were examined. To this end, the mRNA expression 


\section{A}

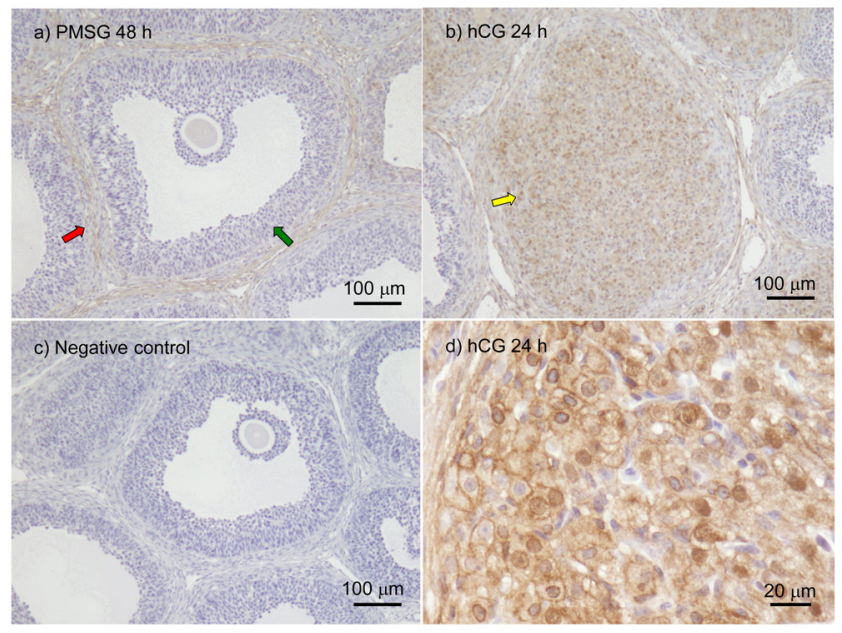

B
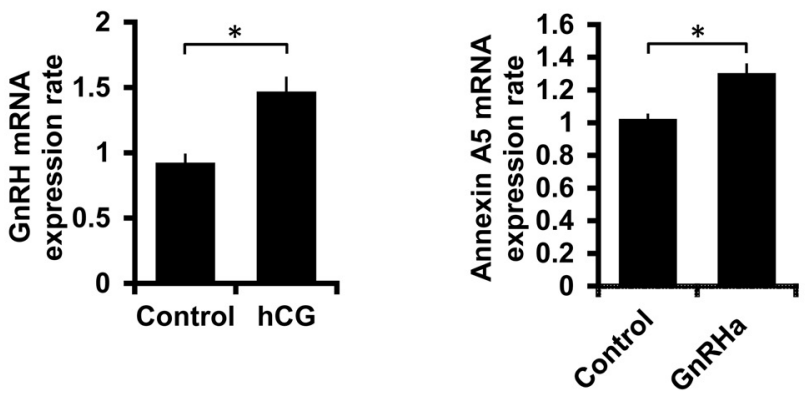

Fig. 2. Expression of ANXA5 and GnRH. (A) Immunohistochemical analysis of ANXA5 in the ovary. a) PMSG (15 IU) was administered to 25 -day-old rats. The red arrow shows the theca layer and the green arrow indicates the granulosa layer. b) Ovaries were collected $48 \mathrm{~h}$ after PMSG treatment and $24 \mathrm{~h}$ after hCG administration. The yellow arrow is the corpus luteum. c) Negative control for immunohistochemistry in which antiserum was replaced with normal rat serum. d) Corpus luteum of hCGtreated rat as in b) at higher magnification. (B) Effects of hCG on GnRH mRNA expression and effects of GnRHa $\left(10^{-8} \mathrm{M}\right)$ on ANXA5 mRNA expression in the primary culture of granulosa cells. Asterisks show a significant difference $(\mathrm{P}<0.01)$.
A

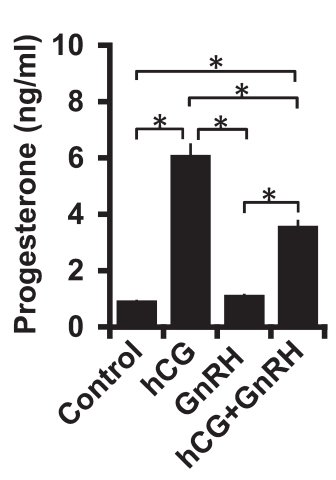

B

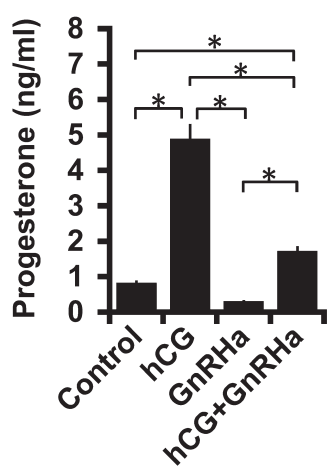

Fig. 3. Effects of GnRH and GnRHa on progesterone production. Granulosa cells were treated with $0.01 \mathrm{IU}$ hCG and (A) $10^{-7} \mathrm{M}$ $\mathrm{GnRH}$ or (B) $10^{-8} \mathrm{M}$ GnRH agonist (GnRHa) for $3 \mathrm{~h}$. Asterisks indicate statistical significance $(\mathrm{P}<0.05)$.
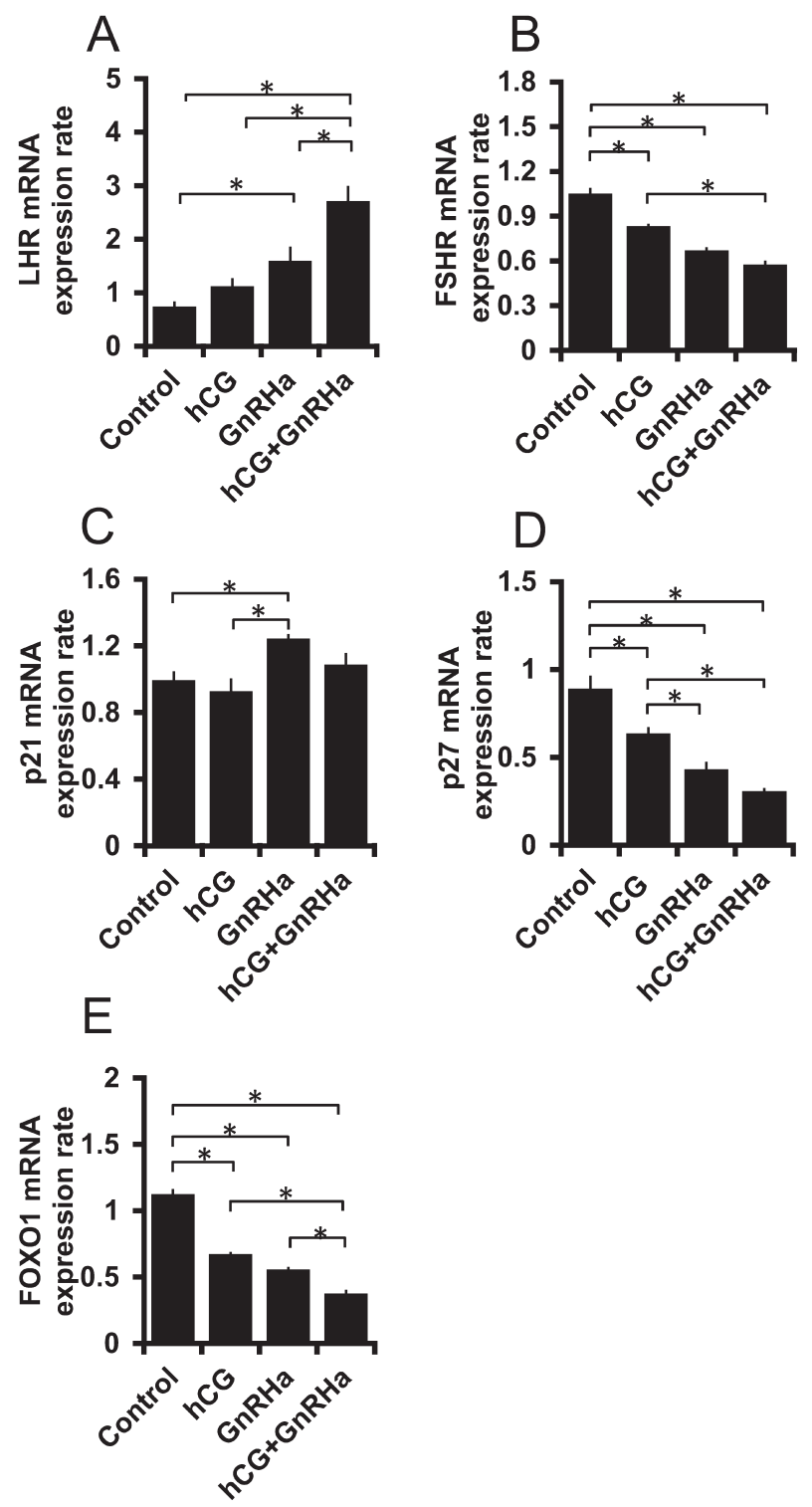

Fig. 4. Effects of GnRHa on the mRNA expression of genes related to granulosa cell differentiation. Granulosa cells were incubated with $0.01 \mathrm{IU}$ hCG and $10^{-8} \mathrm{M}$ GnRH agonist (GnRHa) for $3 \mathrm{~h}$. RNA samples were subjected to RT-qPCR to examine the mRNA expression of (A) LHR, (B) FSHR, (C) p21, (D) p27, and (E) FOXO1. Asterisks indicate values that are significantly different $(\mathrm{P}<0.05)$.

of LHR, FSHR, p21, p27, and FOXO1 was measured. Although hCG only showed a tendency to increase the mRNA expression level of $L H R$, GnRHa significantly augmented its expression (Fig. 4A). GnRHa and hCG showed additive effects on the LHR mRNA expression level; however, FSHR mRNA expression was suppressed by GnRHa (Fig. 4B). GnRHa had stimulatory and inhibitory effects on the endogenous cyclin-dependent kinase (CDK) inhibitors $p 21$ and $p 27$, respectively (Fig. 4C, D). GnRHa significantly increased p21 expression, whereas hCG did not show any such effect. GnRHa 
and hCG synergistically reduced the mRNA expression levels of $p 27$ and $\mathrm{FOXO1}$ (Fig. 4D, E).

\section{Discussion}

The results of this study clearly demonstrate that GnRH synthesized in the ovary is involved in the process of luteinization induced by hCG stimulation, the biological equivalent of LH. We first confirmed that hCG stimulated progesterone production both in vivo and in vitro. Moreover, $24 \mathrm{~h}$ after hCG administration, the granulosa cells became ANXA5-positive, which did not show positive expression prior to hCG treatment. This result suggests the induction of $\mathrm{GnRH}$ action in granulosa cells after hCG administration. We further confirmed that hCG treatment increased the $G n R H$ mRNA expression level and GnRH stimulated $A N X A 5$ mRNA expression during the $3 \mathrm{~h}$ incubation of granulosa cells. GnRH is suggested to be an autocrine effector of granulosa cells. Overall, these data suggest that $\mathrm{GnRH}$ may play a role in the differentiation of granulosa cells to luteal cells under the effect of LH.

Unexpectedly, we found that $\mathrm{GnRH}$ and GnRHa suppressed the hCG-induced progesterone production. We had assumed that progesterone production would be enhanced by $\mathrm{GnRH}$ given that it cooperates with hCG for luteinization, as clarified in this study. This opposing result could indicate the necessity of luteotropic hormone and/or some other ovarian factors to confer the cells with full ability of progesterone production.

ANXA5 is a member of the annexin family of proteins [11, 12]. Although it is well known for its ability to be used as a probe to detect early apoptotic cells [20], its physiological function remains unknown. We previously demonstrated that GnRH stimulates ANXA5 synthesis, which in turn increases gonadotropin secretion from the pituitary gonadotrope [21]. Thus, we also examined the relationship between GnRH and ANXA5 in peripheral tissues and found that GnRH stimulates the expression of ANXA5 in the corpus luteum, mammary epithelial cells, and Leydig cells [7, 16, 17]. A previous study showed that suppression of prolactin secretion caused an increase in GnRH-mediated ANXA5 expression and the apoptosis of luteal cells in the corpus luteum of pseudopregnant rats [7]. In addition, GnRH increased ANXA5 expression and the apoptosis of mammary epithelial cells after weaning [16]. We demonstrated that expression of the GnRH receptor increases in mammary tissues after weaning [22]. Together, these results suggest a close functional relationship between GnRH and ANXA5. Observations of ANXA5 expression further demonstrated that the actions of $\mathrm{GnRH}$ in Leydig cells are influenced by LH [17].

In this study, we determined that the level of ANXA5 increased in granulosa-luteal cells $24 \mathrm{~h}$ after hCG administration. As GnRHa stimulated the mRNA expression of ANXA5 in granulosa cell cultures, these results collectively suggest that GnRH mediates the actions of hCG in granulosa cells. We previously observed that LH-stimulated ANXA5 expression in Leydig cells is mediated by testicular GnRH [17]. Thus, a similar relationship was considered to exist in granulosa cells. Since GnRH and GnRHa suppressed the progesterone production augmented by hCG in the present study, this could indicate that the action of $\mathrm{GnRH}$ on granulosa cells is not simply related to the enhancement of hCG activity. Thus, we decided to examine the effects of $\mathrm{GnRH}$ on the expression of various genes.

Luteinization involves cell proliferation, followed by exit from the cell cycle accompanied by changes in steroid synthesis [9]. In granulosa cells, the FSHR level is decreased while the $L H R$ level is increased after a surge in $\mathrm{LH}[9,10]$, and the steroid synthesis system shifts from estradiol to progesterone. The present data demonstrated an increase in the mRNA expression level of $L H R$ and a decrease in the FSHR expression level upon treatment with hCG and GnRHa. Interestingly, hCG itself did not have a significant effect on $L H R$; however, it augmented the GnRH-induced stimulation of $L H R$ mRNA. FSHR mRNA was slightly but significantly suppressed by hCG. GnRH significantly reduced the expression level of FSHR mRNA and further augmented the suppressive effect of hCG. However, future studies are needed to clarify the relationship between hCG and the GnRHa dose required to increase $L H R$ expression, given that hCG also enhanced GnRH mRNA expression. If the augmentation of $\mathrm{GnRH}$ by hCG was sufficient for inducing the actions of $\mathrm{GnRH}$, hCG would have shown more apparent effects at the gene expression level. Nevertheless, we did observe that GnRH promoted the transition of granulosa cells to luteal cells.

The CDK inhibitors $p 21$ and $p 27$ were examined in the early phase of hCG action. GnRHa augmented $p 21$ and suppressed $p 27$ mRNA expression. Moreover, GnRH and hCG action had additive effects on $p 27$ expression, although the difference in the $p 27$ expression level between the GnRHa-alone group and hCG+GnRHa group was not statistically significant. These results support the idea that GnRH is involved in the transition of granulosa cells to luteal cells. FOXO1 is a transcription factor that is decreased by FSH activity in granulosa cells, and its expression is further suppressed by LH $[23,24]$. Our data demonstrated the synergistic actions of hCG and GnRH on FOXO1 expression.

In summary, the present study demonstrates that mature granulosa cells synthesize GnRH under the effects of hCG, and that GnRH at least partly mediates the effects of hCG in the transition of granulosa cells to luteal cells. Thus, GnRH may be a local regulator of cell differentiation, and ANXA5 may be involved in the process of GnRH action. It is suggested that GnRH-ANXA5 system would play a role physiologically in various tissues in which cell differentiation takes place.

\section{Acknowledgments}

We thank M Nakata for support. This work was supported by the Japan Society for the Promotion of Science KAKENHI, Grant-in-Aid for Scientific Research (17K08128). DT is supported by a scholarship of the Otsuka Toshimi Scholarship Foundation.

\section{References}

1. Schally AV, Bowers CY. Purification of luteinizing hormone-releasing factor from bovine hypothalamus. Endocrinology 1964; 75: 608-614. [Medline] [CrossRef]

2. Reinhart J, Mertz LM, Catt KJ. Molecular cloning and expression of cDNA encoding the murine gonadotropin-releasing hormone receptor. J Biol Chem 1992; 267: 21281-21284. [Medline]

3. Kakar SS, Grantham K, Musgrove LC, Devor D, Sellers JC, Neill JD. Rat gonadotropin-releasing hormone $(\mathrm{GnRH})$ receptor: tissue expression and hormonal regulation of its mRNA. Mol Cell Endocrinol 1994; 101: 151-157. [Medline] [CrossRef]

4. Oikawa M, Dargan C, Ny T, Hsueh AJ. Expression of gonadotropin-releasing hormone 
and prothymosin-alpha messenger ribonucleic acid in the ovary. Endocrinology 1990; 127: 2350-2356. [Medline] [CrossRef]

5. Parborell F, Dain L, Tesone M. Gonadotropin-releasing hormone agonist affects rat ovarian follicle development by interfering with FSH and growth factors on the prevention of apoptosis. Mol Reprod Dev 2001; 60: 241-247. [Medline] [CrossRef]

6. Billig H, Furuta I, Hsueh AJ. Gonadotropin-releasing hormone directly induces apoptotic cell death in the rat ovary: biochemical and in situ detection of deoxyribonucleic acid fragmentation in granulosa cells. Endocrinology 1994; 134: 245-252. [Medline] [CrossRef]

7. Kawaminami M, Shibata Y, Yaji A, Kurusu S, Hashimoto I. Prolactin inhibits annexin 5 expression and apoptosis in the corpus luteum of pseudopregnant rats: involvement of local gonadotropin-releasing hormone. Endocrinology 2003; 144: 3625-3631. [Medline] [CrossRef]

8. Gründker C, Emons G. The role of gonadotropin-releasing hormone in cancer cell proliferation and metastasis. Front Endocrinol (Lausanne) 2017; 8: 187. [Medline] [CrossRef]

9. Stocco C, Telleria C, Gibori G. The molecular control of corpus luteum formation, function, and regression. Endocr Rev 2007; 28: 117-149. [Medline] [CrossRef]

10. Segaloff DL, Wang HY, Richards JS. Hormonal regulation of luteinizing hormone/ chorionic gonadotropin receptor mRNA in rat ovarian cells during follicular development and luteinization. Mol Endocrinol 1990; 4: 1856-1865. [Medline] [CrossRef]

11. Crompton MR, Moss SE, Crumpton MJ. Diversity in the lipocortin/calpactin family. Cell 1988; 55: 1-3. [Medline] [CrossRef]

12. Moss SE. Annexins. Trends Cell Biol 1997; 7: 87-89. [Medline] [CrossRef]

13. Gerke V, Moss SE. Annexins: from structure to function. Physiol Rev 2002; 82: 331-371. [Medline] [CrossRef]

14. Kawaminami M, Kawamoto T, Tanabe T, Yamaguchi K, Mutoh K, Kurusu S, Hashimoto I. Immunocytochemical localization of annexin 5, a calcium-dependent phospholipid-binding protein, in rat endocrine organs. Cell Tissue Res 1998; 292: 85-89. [Medline] [CrossRef]

15. Kawaminami M, Tsuchiyama Y, Saito S, Katayama M, Kurusu S, Hashimoto I. Gonadotropin-releasing hormone stimulates annexin 5 messenger ribonucleic acid expres- sion in the anterior pituitary cells. Biochem Biophys Res Commun 2002; 291: 915-920. [Medline] [CrossRef]

16. Rieanrakwong D, Laoharatchatathanin T, Terashima R, Yonezawa T, Kurusu S, Hasegawa Y, Kawaminami M. Prolactin Suppression of Gonadotropin-Releasing Hormone Initiation of Mammary Gland Involution in Female Rats. Endocrinology 2016; 157 2750-2758. [Medline] [CrossRef]

17. Yao B, Kawaminami M. Stimulation of annexin A5 expression by gonadotropin releasing hormone (GnRH) in the Leydig cells of rats. J Reprod Dev 2008; 54: 259-264. [Medline] [CrossRef]

18. Giambanco I, Pula G, Ceccarelli P, Bianchi R, Donato R. Immunohistochemical localization of annexin V (CaBP33) in rat organs. J Histochem Cytochem 1991; 39: 1189-1198. [Medline] [CrossRef]

19. Pula G, Bianchi R, Ceccarelli P, Giambanco I, Donato R. Characterization of mammalian heart annexins with special reference to CaBP33 (annexin V). FEBS Lett 1990; 277: 53-58. [Medline] [CrossRef]

20. Koopman G, Reutelingsperger CP, Kuijten GA, Keehnen RM, Pals ST, van Oers MH. Annexin V for flow cytometric detection of phosphatidylserine expression on B cells undergoing apoptosis. Blood 1994; 84: 1415-1420. [Medline]

21. Kawaminami M, Etoh S, Miyaoka H, Sakai M, Nishida M, Kurusu S, Hashimoto I. Annexin 5 messenger ribonucleic acid expression in pituitary gonadotropes is induced by gonadotropin-releasing hormone ( $\mathrm{GnRH}$ ) and modulates $\mathrm{GnRH}$ stimulation of gonadotropin release. Neuroendocrinology 2002; 75: 2-11. [Medline] [CrossRef]

22. Terashima R, Laoharatchatathanin T, Kurusu S, Kawaminami M. Augmentation of gonadotropin-releasing hormone receptor expression in the post-lactational mammary tissues of rats. J Reprod Dev 2016; 62: 495-499. [Medline] [CrossRef]

23. Shi F, LaPolt PS. Relationship between FoxO1 protein levels and follicular development, atresia, and luteinization in the rat ovary. $J$ Endocrinol 2003; 179: 195-203. [Medline] [CrossRef]

24. Shen M, Liu Z, Li B, Teng Y, Zhang J, Tang Y, Sun SC, Liu H. Involvement of FoxO1 in the effects of follicle-stimulating hormone on inhibition of apoptosis in mouse granulosa cells. Cell Death Dis 2014; 5: e1475. [Medline] [CrossRef] 